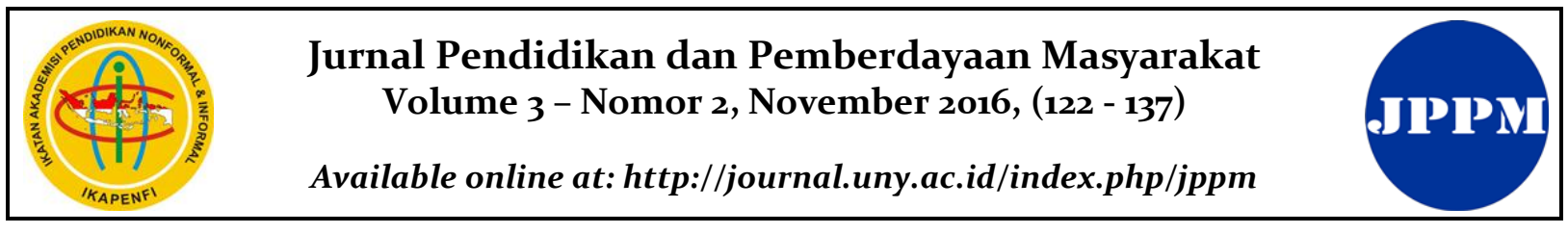

\title{
PEMBELAJARAN PARTISIPATIF KETERAMPILAN BERWIRAUSAHA UNTUK PEMBERDAYAAN EKONOMI WARGA BELAJAR KEJAR PAKET C
}

\author{
Dayat Hidayat \\ Pendidikan Luar Sekolah, Universitas Singaperbangsa Karawang, Jalan HS. Ronggowaluyo \\ Telukjambe Timur, Karawang 41361, Indonesia. \\ Korespondensi Penulis. Email: dayathidayat194@yahoo.com
}

\begin{abstract}
Abstrak
Tujuan penelitian ini adalah untuk menganalisis data tentang kondisi empiris, proses, dan dampak pembelajaran partisipatif model keterampilan fungsional berwirausaha untuk pemberdayaan ekonomi warga belajar Kejar Paket C. Penelitian dilakukan dengan pendekatan kualitatif, metode studi kasus. Teknik pengumpulan data dengan observasi, wawancara mendalam (indepth interview), dan analisis dokumen. Pengumpulan data dilakukan melalui koleksi data, reduksi data, penyajian data, dan pengambilan kesimpulan serta verifikasi data. Hasil penelitian menunjukkan bahwa kondisi pembelajaran partisipatif model keterampilan fungsional berwirausaha Kejar Paket $C$ yang diikuti 20 orang warga belajar berjalan dengan baik. Proses pembelajaran partisipatif keterampilan berwirausaha melibatkan warga belajar dalam perencanaan, pelaksanaan, dan penilaian untuk meningkatkan pengetahuan, keterampilan dan sikap kewirausahaan. Pembelajaran partisipatif keterampilan berwirausaha Kejar Paket $\mathrm{C}$ telah memberikan dampak terhadap peningkatan pengetahuan, sikap dan keterampilan berwirausaha warga belajar untuk meningkatkan kemandirian ekonomi keluarganya.
\end{abstract}

Kata Kunci: pembelajaran partisipatif, keterampilan fungsional berwirausaha, pemberdayaan ekonomi.

\section{PARTICIPATORY LEARNING WITH ENTERPRENEURIAL SKILLS FOR THE ECONOMIC EMPOWERMENT OF KEJAR PAKET C LEARNERS}

\begin{abstract}
This study is aimed at analyzing the data of empirical conditions, process, and the impact of participatory learning with enterpreneurial functional skills model for economical empowerment of Kejar Paket $C$ learners. The study was conducted qualitatively with a case study method. The data collection techniques involved observation, interview and document analysis. The data were obtained through data collection, data reduction, data display, and conclusion drawing/verification. The results of this study showed that the condition of participatory learning with enterpreneurial functional skills model followed by twenty learners of Kejar Paket $C$ run properly. The participatory learning process of entrepreneurial skills engaged the learners in the planning, implementation, and assessment to improve their entrepreneurial knowledge, skills and attitudes. Participatory learning of entrepreneurial skills at Kejar Packet $C$ has an impact on enhancing the learners' enterpreneurial knowledge, attitudes and skills to increase their economic independence.
\end{abstract}

Keywords: partisipatiory learning, enterpernerial skills, economic empowerment.

How to Cite: Hidayat, D. (2016). Pembelajaran partisipatif keterampilan berwirausaha untuk pemberdayaan ekonomi warga belajar kejar paket C. Jurnal Pendidikan dan Pemberdayaan Masyarakat, 3(2), 122-137. doi:http://dx.doi.org/10.21831/jppm.v3i2.11388

Permalink/DOI: http://dx.doi.org/10.21831/jppm.v3i2.11388

Copyright (c) 2016, JPPM, Print ISSN: 2355-1615, Online ISSN: 2477-2992 


\section{Jurnal Pendidikan dan Pemberdayaan Masyarakat, 3 (2), November 2016 - 123}

Dayat Hidayat

\section{PENDAHULUAN}

Pendidikan nonformal dalam berbagai satuannya, bertujuan meningkatkan kualitas sumber daya manusia dan meningkatkan jiwa kewirausahaan warga belajarnya. Pendidikan nonformal dapat diimplementasikan dalam aksi-aksi sebagai pelengkap, pengganti, dan penambah pendidikan formal. Sebagai pelengkap (complementary education) menyajikan berbagai mata pelajaran atau kegiatan belajar yang tidak termuat dalam kurikulum sekolah, tetapi sangat dibutuhkan oleh warga belajar dan masyarakat. Sebagai penambah (suplementary education) memberi kesempatan tambahan pengalaman belajar dalam mata pelajaran yang sama, baik bagi siswa yang masih sekolah ataupun siswa yang telah menamatkan sekolah. Sebagai pengganti (substitusi education), menggantikan fungsi sekolah, yang karena berbagai alasan masih terdapat sebagian masyarakat yang belum terlayani kebutuhan belajarnya. Salah satu satuan pendidikan nonformal yang berfungsi pengganti pendidikan formal adalah program Kejar Paket C.

Keberadaan program Kejar Paket $\mathrm{C}$ di Indonesia, tidaklah terlepas dari berkembangnya model pendidikan nonformal dalam memecahkan permasalahan pendidikan formal. Berkaitan dengan model pendidikan nonformal tersebut, Sudjana (2004, pp.112113) mengemukakan bahwa model pendekatan paralel pendidikan nonformal dengan pendidikan formal, menekankan kedua jalur tersebut berjalan berdampingan dan saling menunjang antara yang satu dengan lainnya. Para peserta didik adalah mereka yang tidak mempunyai kesempatan untuk mengikuti pendidikan formal, yang putus jenjang pendidikan atau tidak melanjutkan jenjang pendidikan yang lebih tinggi, dan anak-anak yang putus sekolah. Pendidikan paralel ini mempunyai tujuan ganda yaitu pertama, untuk memberikan kesempatan pendidikan kepada para siswa agar mereka dapat mengikuti ujian-ujian terminal jenjang pendidikan formal, dan kedua, agar para siswa dapat mengembangkan kepercayaan dan kemampuan diri untuk menghadapi kenyataan kehidupan di masyarakat.
Dalam berbagai keadaan program Kejar Paket $C$ dilaksanakan di berbagai tempat. Program Kejar Paket $C$ di Desa Tanjungpakis Kecamatan Pakisjaya Kabupaten Karawang diikuti 20 orang warga belajar. Proses pembelajaran Kejar Paket C direncanakan, dilaksanakan dan dievaluasi sesuai dengan prinsip-prinsip pembelajaran partisipatif melalui model keterampilan fungsional dan kewirausahaan. Dalam operasionalisasinya, program Kejar Paket $\mathrm{C}$ diharapkan dapat dilaksanakan pihak yang berkompeten sehingga mempunyai dampak yang kuat bagi peningkatan keterampilan fungsional dan kewirausahaan warga belajarnya. Tantangan dan hambatan utama, yaitu rendahnya pengetahuan, sikap dan keterampilan fungsional dan kewirausahaan warga belajar Kejar Paket C perlu diatasi. Salah satunya menerapkan pembelajaran partisipatif model keterampilan fungsional dan kewirausahaan kepada warga belajar Kejar Paket C. Tujuan pembelajaran partisipatif model keterampilan fungsional dan kewirausahaan dilakukan agar warga belajar Kejar Paket $C$ dapat meningkatkan keterampilannya dan memiliki sikap kewirausahaan untuk mengembangkan usaha sehingga berdampak pada peningkatan kesejahteraan ekonomi keluarga dengan mengoptimalkan berbagai kondisi sosial, budaya dan sumber daya alam yang berbasis pada potensi lokal.

Perencanaan pembelajaran partisipatif keterampilan fungsional berwirausaha dalam meningkatkan pemberdayaan ekonomi warga belajar Kejar Paket $C$ dilaksanakan mulai dari tahap identifikasi kebutuhan belajar secara bersama-sama antara pengelola dan warga belajar terorganisasi dan dikelola oleh warga belajar, (2) program pendampingan dari pengelola Paket $C$ untuk meningkatkan proses pembelajaran yang lebih banyak mengandalkan pada komponen pendamping dalam mengusahakan perubahan tingkah laku warga belajar, (3) pembelajaran pendampingan dari pengelola Kejar Paket C lebih banyak berorientasi pada tujuan belajar yang hasilnya langsung dapat dimanfaatkan oleh warga belajar untuk meningkatkan taraf hidupnya dan mengembangkan partisipasinya dalam usaha usaha yang menyangkut kepentingan masyarakat, (4) 
proses pendampingan menitikberatkan sumber-sumber yang tersedia di masyarakat baik sumber manusiawi, maupun alam agar dengan demikian terjadi saling memanfaatkan antara warga belajar dengan lingkunganya, dan (5) proses pendampingan lebih memperhatikan segi manusiawi warga belajar dengan menghargai potensi dan kemampuan yang dimiliki serta dengan menekankan pada usaha warga belajar dalam memanfaatkan potensi dan menampilkan kemampuan itu untuk melakukan kegiatan berpikir dan berbuat guna mencapai tujuan pembelajaran yang menjadi milik mereka dalam menyelenggarakan Kejar Paket C.

Proses pembelajaran pada hakekatnya merupakan jawaban terhadap masalah belajar yang dihadapi oleh warga belajar Kejar paket $C$ di Desa Tanjungpakis. Kebutuhan belajar terpilih adalah merupakan prioritas yang dijawab atau kebutuhan belajar yang perlu dipenuhi secara cepat sebelum menjawab kebutuhan belajar lainnya. Kebutuhan terpilih ini merupakan masalah belajar atau pemicu terhadap masalah lainnya, dan hal tersebut merupakan dasar pengembangan program pembelajaran itu sendiri. Untuk itu, program belajar Kejar Paket $C$ sebenarnya pemecahan terhadap masalah belajar atau dalam kasus ini sebagai program yang akan digunakan untuk memenuhi kebutuhan belajar warga belajar yang mengikuti pembelajaran Kejar Paket $C$.

Belajar sebagai hasil merupakan hasil yang dicapai dalam setiap pembelajaran. Hasil pembelajaran meliputi aspek pengetahuan (cognitive), keterampilan (psicomotor) dan sikap (affective). Hasil perubahan pengetahuan ialah pemilikan atau penambahan sesuatu yang dipelajari, misalnya tentang mata pelajaran dalam bidang studi tertentu. Perubahan pengetahuan (cognitive) tersebut meliputi enam aspek, yaitu pengetahuan (knowledge), pengertian (comprehension) penerapan (application), analisis, sintesis dan evaluasi. Dalam aspek afektif, yaitu perubahan yang berhubungan dengan minat, sikap, nilai-nilai, penghargaan dan penyesuaian diri. Perubahan keterampilan dapat diartikan sebagai peningkatan kemampuan di bidang keterampilan sebgai hasil dari proses belajar.
Peningkatan pendapatan untuk kemandirian ekonomi warga belajar paket $C$, merupakan dampak yang diharapkan setelah mengikuti program pembelajaran keterampilan. Dampak yang diharapkan setelah warga belajar Kejar Paket $C$ dalam mengikuti proses pembelajaran keterampilan fungsional yang sesuai dengan kemampuan diri dan potensi lokal warga belajar. Kemandirian tersebut merupakan perubahan taraf hidup yang ditandai dengan perolehan kesempatan pekerjaan atau berwirausaha, perolehan atau peningkatan pendapatan, kesehatan, dan penampilan diri.

Strategi pembelajaran partisipatif keterampilan fungsional berwirausaha bagi warga belajar Kejar Paket $C$ di desa Tanjungpakis merupakan pengembangan kewirausahaan berbasis potensi lokal yang menitikberatkan proses peningkatan pertumbuhan ekonomi yang dimotori oleh warga belajar dengan memanfaatkan potensi-potensi lokal untuk pembangunan dalam upaya untuk memperbaiki kesejahteraan ekonomi masyarakat lokal. Lincolin \& Elan, dkk, (2011, p.95) mengemukakan bahwa strategi pengembangan kewirausahaan ini yang menggunakan pendekatan kewilayahan yang mengandalkan terutama sekali pada kebutuhan, potensi, dan pelaku lokal dari suatu daerah tertentu (locality).

Pada pelaksanaan pembelajaran partisipatif keterampilan fungsional berwirausaha bagi warga belajar Kejar Paket C, melibatkan berbagai pihak terkait, seperti ketua pengelola Kejar Paket C, ketua kelompok belajar dan tokoh masyarakat. Pembelajaran partisipatif keterampilan fungsional berwirausaha bagi warga belajar Kejar Paket $C$ ini secara keseluruhan berjalan sebagai berikut: (1) Ketua Kejar Paket C yang melaksanakan kegiatan usaha mempelajari sampai memahami skenario pembelajaran partisipatif keterampilan fungsional berwirausaha; (2) Ketua Kejar PaketC yang melaksanakan pembelajaran partisipatif keterampilan fungsional berwirausaha menjalin kerjasama dengan dunia usaha dan industri (DUDI), perbankan dan perusahaan 'modal ventura' masing-masing minimal satu unit usaha untuk menjadi mitra kelompok usaha; (3) Kegiatan kewirausahaan di setiap Kejar Paket $\mathrm{C}$ dikoordina- 


\section{Jurnal Pendidikan dan Pemberdayaan Masyarakat, 3 (2), November 2016 - 125 \\ Dayat Hidayat}

sikan dengan mitra usaha terutama untuk praktek dan implementasi kewirausahaan.

Berdasarkan kondisi tersebut, tujuan yang ingin dicapai dalam penelitian ini untuk menganalisis kondisi empiris warga belajar, proses pembelajaran partisipatif model keterampilan fungsional, dan pemberdayaan ekonomi warga belajar setelah mengikuti Kejar Paket C. Penelitian ini bertujuan menggambarkan dan menganalisis fakta dengan interpretasi yang tepat terhadap pembelajaran partisipatif model keterampilan fungsional berwirausaha untuk meningkatkan pemberdayaan ekonomi warga belajar Kejar Paket C di Desa Tanjungpakis Kecamatan Pakisjaya Kabupaten Karawang.

\section{METODE}

Penelitian ini dilakukan menggunakan pendekatan kualitatif yang bertujuan menganalisis informasi tentang fenomena utama yang dieksplorasi dalam penelitian, partisipan, dan lokasi penelitian tentang pembelajaran partisipatif model keterampilan fungsional berwirausaha untuk pemberdayaan ekonomi warga belajar Kejar Paket C di Desa Tanjungpakis. Tujuan penelitian ditulis dengan istilah-istilah "teknis" penelitian yang bersumber dari bahasa penelitian kualitatif (Schwandt, 2007 dalam Cresswell, 2013, p.167). Pendekatan ini digunakan karena lebih mudah apabila berhadapan dengan kenyataan, dan menyajikan secara langsung hakekat hubungan antara peneliti dengan responden, lebih peka dan lebih dapat menyesuaikan diri dengan banyak penajaman pengaruh bersama terhadap pola-pola nilai yang dihadapi (Moleong, 2010, p.5).

Metode dalam penelitian ini adalah studi kasus yang bertujuan memperoleh gambaran kasus secara detail, analisis tema atau pokok bahasan, dan interpretasi peneliti atau penegasan kasus. Interpretasi ini dapat disebut "pelajaran yang dipelajari" (Guba \& Lincolin, 1989 dalam Milan \& Schumacher, 1997, p. 57). Emzir (2010) mengemukakan bahwa metode studi kasus merupakan suatu penelitian kualitatif yang berusaha menemukan makna, menyelidiki proses, dan memperoleh pengertian dan pemahaman yang mendalam dari individu, kelompok dan situasi. Melalui metode kasus ini dianalisis kondisi empiris, proses yang meliputi perencanaan, pelaksanaan, penilaian, hasil dan dampak penerapan pembelajaran partisipatif model keterampilan fungsional berwirausaha untuk pemberdayaan ekonomi warga belajar Kejar Paket C di Desa Tanjungpakis.

Penelitian ini dilaksanakan pada bulan April sampai dengan Agustus 2015 pada program Kejar Paket $C$ di Desa Tanjungpakis Kecamatan Pakisjaya Kabupaten Karawang. Sebagai sumber informasi, subjek dalam penelitian ini ditentukan secara purposive sampling yang terdiri data dari satu orang pengelola, satu orang tutor dan tiga orang warga belajar Kejar Paket C di Desa Tanjungpakis.

Penelitian ini dilakukan melalui tahapan: (1) orientasi untuk mendapatkan informasi tentang apa yang penting untuk ditemukan, (2) eksplorasi untuk menentukan sesuatu secara terfokus, dan (3) member check untuk mengecek temuan menurut prosedur dan memperoleh laporan akhir (Nasution, 1996, pp. 33-34).

Data yang dikumpulkan dalam penelitian ini adalah data kualitatif yang ditunjang pula data kuantitatif. Untuk mengumpulkan data digunakan instrumen yaitu observasi, wawancara mendalam, dan analisis dokumentasi sebagai sumber data triangulasi yang dapat dipertanggungjawabkan keakuratannya. Teknik ini digunakan untuk melacak atau membuktikan kebenaran data yang dikumpulkan untuk dianalisis tentang pembelajaran partisipatif model keterampilan fungsional berwirausaha Kejar Paket $C$ di Desa Tanjungpakis.

Analisis data yang digunakan dalam penelitian ini adalah model interaktif yang dilakukan melalui tahapan (1) koleksi data (data collection), (2) reduksi data (data reductionaI), (3) penyajian data (data display) dan (4) penarikan kesimpulan/verifikasi (conclusion/verifying). Untuk lebih jelasnya dapat dilihat pada Gambar 1. 


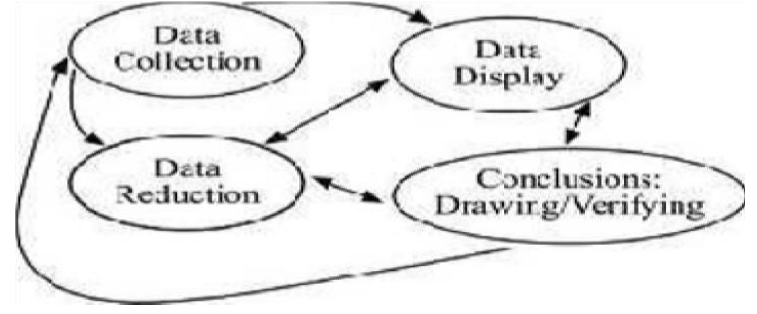

Gambar 1. Komponen Analisis Data Model Interaktif (Miles \& Huberman(1994: 19-20).

Koleksi Data, sebagai bentuk analisis yang mempertajam, memilih, memfokuskan, membuang, dan menyusun data dalam suatu cara dimana kesimpulan akhir dapat digambarkan dan diverifikasi (Emzir, 2010). Data tentang pembelajaran partisipatif model keterampilan fungsional berwirausaha Kejar Paket $C$ yang diperoleh dari berbagai sumber dan metode sangat memungkinkan untuk mendapatkan data yang banyak dan belum relevan. Selanjutnya dilakukan reduksi data dengan cara membuat rangkuman yang inti, proses dan pernyataan yang perlu dijaga sehingga tetap berada dalam data penelitian. Berikutnya, display data yang dimaksudkan untuk menemukan pola-pola yang bermakna serta memberikan kemungkinan adanya penarikan kesimpulan. Dalam penelitian ini terdapat beberapa fokus penelitian yang selanjutnya dihubungkan atau dikaitkan untuk menemukan maknanya, kemudian disusun secara sistematis dari bentuk informasi yang kompleks dan diseleksi menjadi informasi yang sederhana. Tahap terakhir dilakukan penarikan kesimpulan yang bertujuan untuk mengutarakan kesimpulan dari data yang diperoleh. Penarikan kesimpulan dilakukan dengan cara membandingkan kesesuaian antara pernyataan dari subjek penelitian dengan makna yang terkandung dalam konsep dasar penelitian tentang pembelajaran partisipatif model keterampilan fungsional berwirausaha untuk pemberdayaan ekonomi warga belajar Kejar Paket $C$.

\section{HASIL DAN PEMBAHASAN}

\section{Kondisi Empiris Program Kejar Paket C}

Program Kejar Paket C di Desa Tanjungpakis dilaksanakan menggunakan strategi pengelolaan sebagai berikut: (1) strategi produksi, untuk menentukan keluaran apa yang akan dihasilkan Kejar Paket $C$ yaitu kesetaraan SLTA dan program belajar keterampilan fungsional yang dibutuhkan warga belajar, (2) strategi proses, sesuai tujuan pembelajaran kesetaraan dan keterampilan fungsionalnya secara efektif dan efisien sehingga pembelajaran memperoleh hasil yang terbaik, (3) strategi lokasi, untuk menentukan tempat proses pembelajaran yang dapat dilaksanakan secara fleksibel sesuai dengan kondisi warga belajar belajar, dan (4) strategi sumber daya manusia, sebagai cara pemberdayaan pengelolaan PKBM agar mampu mengidentifikasi kebutuhan belajar, tutor, fasilitas menyusun program pembelajaran, menempatkan nara sumber serta mengatur sarana prasarana yang tersedia.

Beberapa hal yang dilakukan dalam menentukan strategi ini adalah: (1) mengidentifikasi kebutuhan warga belajar yang dilakukan secara bertahap, (2) pembinaan tenaga pengelola (tutor, fasilitator, dan pengelola), (3) penyebaran informasi pada masyarakat secara luas dan intensif tentang keberadaan PKBM, (4) menjalin kerjasama lintas sektoral baik pemerintah maupun non pemerintah, (5) program yang ada dilaksanakan secara bertahap dan berkesinambungan dengan memperhatikan kondisi objektif wara mesyarakat sekitar PKBM dan daya dukung yang ada, dan (6) menciptakan suasana kekeluargaan untuk kelancaran dan keberhasilan program Kejar Paket $C$.

Dalam penyelenggaraan program Kejar Paket $C$ di Desa Tanjungpakis, seluruh unsur berinteraksi dalam satu sistem pembelajaran. Unsur-unsur tersebut terdiri atas: (1) 20 orang warga belajar, (2) 8 orang tutor, (3) 5 orang penyelenggara, 4) materi pembelajaran Paket $C$ dan keterampilan fungsional berwirausaha yang meliputi: (a) kewirausahaan, (b) keterampilan produksi, (c) pengelolaan keuangan, (d) pengelolaan usaha, dan (e) pemasaran hasil produksi. Bahan belajar yang digunakan adalah: (a) bahan pokok berupa Modul Paket $C$ yang disusun berdasarkan atas tingkat kesetaraan dari tiap mata pelajaran, (b) bahan pelengkap berupa alat peraga untuk setiap mata pelajaran yang telah disediakan, serta buku-buku bacaan lainnya yang dinilai setara SLTA untuk setiap mata pelajaran, dan (c) bahan belajar keterampilan berupa berbagai jenis keteram- 


\section{Jurnal Pendidikan dan Pemberdayaan Masyarakat, 3 (2), November 2016 - 127}

Dayat Hidayat

pilan fungsional berusaha yang dipelajari sesuai dengan minat dan kemampuan warga belajar, (5) tempat pembelajaran dilaksanakan di Desa Tanjungpakis, (6) waktu pembelajaran dilaksanakan setiap minggu 3 kali pertemuan mulai dari hari Senin s/d Kamis, rata-rata setiap hari 6 jam pembelajaran. Untuk pembelajaran keterampilan berusaha dilaksanakan seminggu 2 kali pertemuan selama 4 jam pembelajaran, (7) untuk memotivasi warga belajar agar aktif dan bergairah mengikuti Kejar Paket $\mathrm{C}$ diberikan ragi belajar dalam bentuk berbagai keterampilan berusaha yang dapat dijadikan bekal atau modal mereka dapat memperoleh penghasilan serta hidup mandiri, dan (8) sumber dana penyelenggaraan Kejar Paket $C$ terdiri atas anggaran proyek PNFI dan swadaya masyarakat.

Kemitraan yang dilaksanakan oleh penyelenggara Kejar Paket C di Desa Tanjungpakis antara lain dengan lembaga/instansi yang terkait dengan kegiatan-kegiatan PNFI di masyarakat, PKBM, seperti dengan Dinas Pendidikan dan Kebudayaan, baik dengan Dinas Pendidikan dan Kebudayaan Kecamatan Pakisjaya maupun Kabupaten Karawang. Selain itu, berkoordinasi dengan Dinas Tenaga Kerja Kabupaten Karawang, dan instansi lain yang terkait dengan penyelenggaraan berbagai kegiatan PNFI.

Seperti dikemukakan tersebut bahwa pembelajaran Kejar Paket C dilaksanakan untuk meningkatkan keterampilan berwirausaha warga belajar. Kewirausahaan menurut Kao (1991, p.14) dalam Sudjana (2004, p.131) mengemukakan bahwa: "kewirausahaan adalah sikap dan perilaku wirausaha. Wirausaha ialah orang yang inovatif, antisipatif, inisiatif, pengambil resiko, dan berorientasi laba." Artinya kewirausahaan merupakan sikap dan perilaku orang yang inovatif, antisipatif, inisiatif, pengambil resiko, dan berorientasi laba. Kewirausahaan pada dasarnya merupakan jiwa diri seseorang yang diekspresikan melalui sikap dan perilaku yang kreatif dan inovatif untuk melakukan kegiatan berusaha. Orang yang memiliki jiwa kewirausahaan dapat melaku- kan kegiatan berusaha atau menjadi pelaku kewirausahaan atau lebih dikenal dengan sebutan wirausaha.

Secara etimologi kewirausahaan merupakan nilai yang diperlukan untuk memulai suatu usaha (start-up phase) atau suatu proses dalam mengerjakan suatu yang baru (creative) dan sesuatu yang berbeda (innovative). Hisrich-Peters (1995) dalam Alma (2004, p.26) mengemukakan bahwa: "Enterpreneurship is the process of creating something different with vaule by devoting the necessary time and effort, assuming the accompanying financial, psyhic, and social risk, and receiving the resulting rewards of monetary and personal satisfaction and independence. (Kewirausahaan adalah proses menciptakan sesuatu yang lain dengan menggunakan waktu dan kegiatan disertai modal dan resiko serta menerima balas jasa dan kepuasan serta kebebasan). Suryana (2007, p.10) juga mengemukakan bahwa: kewirausahaan merupakan terjemahan dari "entrepreneurship", yang dapat diartikan sebagai "the backbone of economy", yaitu syaraf pusat perekonomian atau sebagai 'tailbone of economy', yaitu pengendali perekonomian suatu bangsa.

Kompetensi inti seorang wirausaha ialah inovatif dan kreatif. Tujuan pembelajaran keterampilan berusaha bagi warga belajar Kejar Paket $C$ diarahkan pada pembentukan sikap dan perilaku warga belajar Kejar Paket $C$ yang memiliki kemampuan inovatif serta bermanfaat bagi masyarakat luas. Karenannya yang bersangkutan harus selalu ingin tahu, mencoba, bermain, dan intuitif. Tujuan pembelajaran keterampilan berwirausaha hendaknya dapat memberikan bekal bagi warga belajar Paket $C$ melalui tiga dimensi, yaitu aspek managerial skil, production technical skill, dan personality developmental skill. Ketiga aspek utama tersebut intinya ialah menanamkan sikap dan semangat mandiri serta kemampuan kerja sama dan tertanamnya paradigma wirausaha yang secara sederhana dapat digambarkan sebagai berikut: 


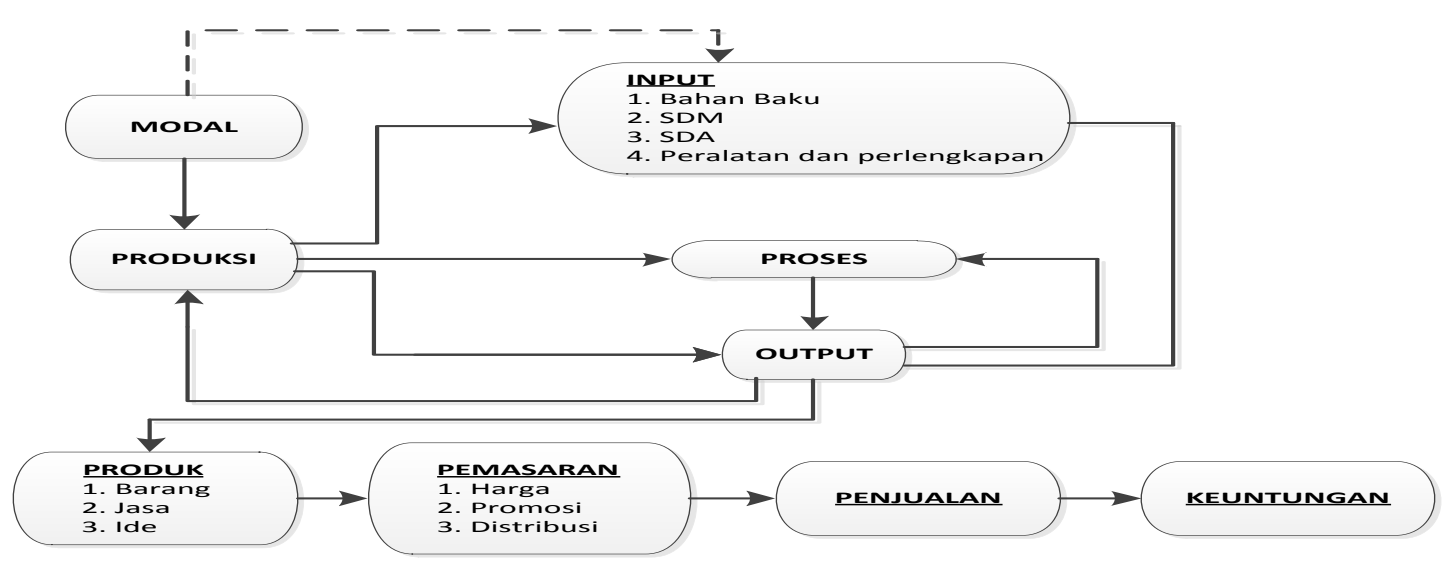

Gambar 2. Paradigma Kewirausahaan (Suherman, 2010, p.23)

Berdasarkan paradigma (pola pikir) wirausaha, dapat diartikan berarti jika seseorang dari warga belajar Paket $\mathrm{C}$ ingin menjadi wirausahawan harus mandiri untuk melakukan kerja sama atau harus mampu melaksanakan kerjasama dalam kemandirian. Hal tersebut diarahkan untuk pengadaan modal dan melakukan produksi mulai dari penyediaan input, proses sampai menghasilkan output berupa produk dalam bentuk barang, jasa maupun ide. Selanjutnya produk tersebut dipasarkan dan atau dijual agar mendapat keuntungan yang pada gilirannya dari keuntungan tersebut dapat dikembangkan untuk memproduksi pada periode berikutnya.

\section{Proses Pembelajaran Partisipatif Model Keterampilan Fungsional dan Kewirausahaan}

Perencanaan pembelajaran Kejar Paket $C$ di Desa Tanjungpakis dimulai dengan rekruitmen tutor yang memiliki kualifikasi di bidangnya. Rekruitmen tutor dilakukan sesuai dengan petunjuk pelaksanaan program PNFI yang lebih dulu harus memiliki pendidik/tutor yang ahli di bidangnya. Setelah itu penyelenggara melakukan rekruitmen warga belajar yang berasal dari keluarga kurang mampu. Perencanaan pembelajaran Kejar paket $C$ ini merupakan kebijakan kepala Desa Tanjungpakis untuk menggali dan memanfaatkan sumber-sumber yang tersedia secara efektif dan efisien untuk mencapai tujuan sosio-ekonomi atau sosio-kultural masyarakatnya. Perencanaan program Kejar Paket $C$ ini merupakan fungsi awal dari keseluruhan kegiatan pengelolaan dan merupa- kan proses sistematis untuk pengambilan keputusan tentang apa yang akan dilaksanakan, mengapa dilaksanakan, tujuan yang ingin dicapai, waktu yang dibutuhkan, bagaimana proses pelaksanaannnya, daya dukung apa yang tersedia, serta berbagai resiko dan kemungkinan hambatan yang akan dihadapi dalam penyelenggaraan Kejar Paket C. Rekrutmen warga belajar Kejar Paket C dilakukan melalui sosialisasi di tingkat RT/ RW. Rekruitmen yang dilaksanakan dengan cara menginformasikan melalui forum rapat minggon yang diselenggarakan di Desa Tanjungpakis. Dengan cara demikian calon warga belajar yang dijaring nantinya akan sesuai dengan persyaratan yang telah ditetapkan dalam petunjuk pelaksanaan program Kejar Paket C.

Proses pembelajaran Kejar Paket C diawali perumusan tujuan pembelajaran yang terdiri atas tujuan program, tujuan kurikuler, tujuan pembelajaran umum dan tujuan pembelajaran khusus. Setiap jenis tujuan tersebut memiliki karakteristik masing-masing, terutama berkaitan dengan ruang lingkup kemampuan yang akan dicapainya. Tujuan-tujuan tersebut ada yang bersifat tujuan akhir (ultimate goal) dari program, dan tujuan antara (intermadate goals). Penetapan kedua tahap tujuan ini didasarkan atas kemampuan yang harus diperoleh warga belajar setelah mengikuti Kejar Paket C. tersebut. Tujuan ini berkaitan dengan kemampuan yang akan diperoleh setelah warga belajar mengikuti pembelajaran Paket C. Tujuan program ini dijabarkan lagi ke dalam tujuan kurikuler dari setiap 


\section{Jurnal Pendidikan dan Pemberdayaan Masyarakat, 3 (2), November 2016 - 129}

Dayat Hidayat

mata pelajaran yang dirancang dalam program pembelajaran tersebut.

Tutor Kejar Paket C mengemukakan bahwa tujuan kurikuler atau tujuan untuk setiap mata pelajaran merupakan pernyataan tujuan yang mencakup pencapaian kemampuan yang berkaitan dengan kemampuan yang dapat diperoleh peserta setelah mengikuti mata pelajaran tersebut. Setiap mata pelajaran adakalanya memiliki kemampuan kognitif, psikomotor, dan afektif yang berkaitan satu sama lain. Bentuk pernyataan tujuan semacam ini mencakup: pengungkapan siapa peserta program belajar, tingkah laku secara umum yang akan dicapai, kriteria pencapaian dari mata pelajaran Paket C. Pernyataan tujuan kurikuler ini tidak terlepas dari tugas yang harus diselesaikan berkaitan dengan pembelajaran Paket C secara keseluruhan. Kejelasan posisi mata pelajaran Paket $C$ perlu jelas untuk menetapkan pernyataan yang harus dicapai warga belajar Paket C. Posisi mata pelajaran dalam kaitannya dengan struktur mata pelajaran dalam program yang bersangkutan, yang pada hakekatnya struktur terdiri atas Mata Pelajaran Dasar Umum Paket C setara SLTA dan Mata Pelajaran Dasar Keterampilan Kewirausahaan.

Perencanaan pembelajaran merupakan faktor yang sangat mendasar dan menentukan keberhasilan pencapaian tujuan pembelajaran. Tanpa adanya perencanaan yang jelas dan terukur kita tidak akan mengetahui dengan pasti apakah proses pembelajaran yang dilaksanakan berhasil atau tidak. Perencanaan pembelajaran yang menyeluruh mengandung efektivitas dan efisiensi sistem dan proses, yang mencerminkan komponenkomponen yang secara sistematis saling berhubungan dan saling mempengaruhi. Komponen-komponen tersebut menurut Abdulhak (1995) meliputi: (1) alasan mengapa pembelajaran dilaksanakan, (2) tujuan pembelajaran yang akan dicapai, (3) tindakan yang akan dilaksanakan untuk mencapai tujuan pembelajaran tersebut, (4) daya dukung yang tersedia, baik manusia maupun nonmanusia, (5) bagaimana proses pembelajaran tersebut dilaksanakan, dan (6) waktu yang dibutuhkan untuk melaksanakan pembelajaran tersebut.
Perencanaan adalah suatu proses yang sistematis dalam pengambilan keputusan tentang tindakan yang akan dilakukan pada waktu yang akan datang. Sistematis berarti bahwa perencanaan dilakukan dengan menggunakan prinsip tertentu dalam proses pengambilan keputusan, penggunaan pengetahuan dan teknik secara ilmiah, serta tindakan atau kegiatan yang terorganisasi. Friedman (1978) dalam Sudjana (2007) mengemukakan bahwa: "planning is a process by which a scientific technical and knowledge is joined to organized action" (perencanaan adalah suatu proses yang menggabungkan pengetahuan dan teknik ilmiah ke dalam kegiatan yang terorganisasi).

Selanjutnya Waterson (1965) dalam Sudjana (2007, p. 61) mengungkapkan "pada hakekatnya perencanaan merupakan usaha sadar, terorganisasi, dan terus menerus dilakukan untuk memilih alternatif yang terbaik dari sejumlah alternatif tindakan guna mencapai tujuan". Pada prinsipnya perencanaan memiliki fungsi: (1) untuk mengurangi adanya hambatan-hambatan serta pemborosan, sehingga semua yang tercakup di dalamnya dapat dimanfaatkan sebaik mungkin, (2) sebagai pelayanan yang berupa prosedur di dalam proses pencapaian tujuan, (3) sebagai penyeimbang daripada komponen-komponen yang terlibat di dalamnya. Perencanaan merupakan bagian awal dari manajemen.

Perencanaan pembelajaran Kejar Paket C merupakan suatu proses yang sistematis dalam pengambilan keputusan tentang tindakan yang akan dilakukan pada waktu yang akan datang untuk mencapai tujuan pembelajaran yang berkaitan dengan keterampilan fungsional dan kewirausahaan warga belajarnya. Disebut sistematis karena perencanaan itu digunakan dengan menggunakan prinsipprinsip tertentu. Prinsip-prinsip tersebut mencakup proses pengambilan keputusan, penggunaan pengetahuan dan teknik secara ilmiah, serta tindakan atau kegiatan yang terorganisasi.

Pada tahap perencanaan pembelajaran keterampilan fungsional berwirausaha bagi warga belajar Kejar Paket C ini dilakukan proses pembinaan keakraban, identifikasi kebutuhan belajar, sumber belajar dan 
kemungkinan hambatan belajar, perumusan tujuan pembelajaran dan penyusunan program pembelajaran. Secara teknis perencanaan pembelajaran Kejar Paket C di Desa Tanjungpakis pertama, pengelola membantu calon warga belajar dalam mendiagnosis kebutuhan belajar yang ingin dicapai. Identifikasi kebutuhan belajar secara menyeluruh yang dilakukan untuk meningkatkan pengetahuan, sikap dan keterampilan kewirausahaan yang ingin diperoleh warga belajar. Keterlibatan warga belajar dalam kegiatan identifikisi kebutuhan belajar, sumber dan kemungkinan hambatan pembelajaran Kejar Paket $C$ ini merupakan satu kesatuan dalam pelaksanaan pembelajaran partisipatif keterampilan fungsional berwirausaha. Dalam hal ini pengelola Paket $C$ membantu warga belajar menyusun tujuan pembelajaran untuk memberikan arah kegiatan belajar, sebagai dasar untuk pelaksanaan pembelajaran dan pengadaan unsur unsur pembelajaran yang tepat, dan sebagai tolok ukur dalam penilaian pembelajaran. Pengelola Kejar Paket $C$ bersama-sama warga belajar memilih prioritas tujuan pembelajaran yang akan dicapai berdasarkan masalah, dukungan dan hambatan yang tersedia atau yang dapat disediakan. Selain itu, pengelola, warga belajar dan semua pihak yang terlibat dalam merumuskan tujuan pembelajaran dilakukan untuk menentukan komponen komponen program, pembelajaran seperti warga belajar, sumber belajar, bahan belajar, implementasi proses pembelajaran, alat evaluasi, fasifitas, alat alat, dan biaya. Dalam menentukan kebutuhan belajar, faktor pengalaman warga belajar menjadi modal sosial, budaya, SDM dan SDA yang sangat penting untuk diperhatikan. Dalam merancang, pengalaman belajar ini pengelola Paket $C$ membantu warga belajar menerapkan prinsip prinsip pengorganisasian bahan belajar dan membantu warga belajar menentukan model pembelajaran yang akan ditempuh.

Kedua, membantu warga belajar menentukan Kelompok Belajar Paket C. Situasi yang baik untuk melibatkan warga belajar dalam perencanaan pembelajaran agar pelaksanaan pembelajaran dapat berlangsung secara efektif dan efisien. Kelompok Belajar Paket $\mathrm{C}$ sebagai salah satu satuan pendidikan nonformal mengandung empat ciri, yaitu adanya kebersamaan kebutuhan dan motivasi, reaksi dan kecakapan yang berlainan, struktur organisasi, dan normanorma kelompok (Sudjana, 2004, p.136). dan Ketiga, menyusun program pembelajaran keterampilan fungsional kewirausahaan untuk dan menetapkan bahan belajar, metode, teknik, waktu, evaluasi, alat-alat dan fasilitas proses pembelajaran.

Proses pembelajaran pembelajaran Kejar Paket $\mathrm{C}$ merupakan perubahan disposisi atau kemampuan warga belajar yang dicapai melalui usaha orang itu, dan perubahan itu bukan diperoleh secara langsung melainkan dari proses pertumbuhan dirinya secara alamiah. Pembelajaran Kejar Paket C merupakan usaha yang disengaja oleh warga belajar untuk mencapai tujuan belajarnya. Dikatakan sebagai usaha untuk mencapai tujuan, yaitu perubahan tingkah laku, memiliki arti bahwa belajar merupakan bagian dari tingkah laku warga belajar yang mencerminkan adanya sikap dan perbuatan untuk belajar pada diri warga belajar. Dikatakan sebagai suatu usaha untuk perubahan tingkah laku, karena kegiatan belajar merupakan upaya untuk meningkatkan disposisi dan kemampuannya setelah mengikuti pembelajaran Kejar Paket C. Perubahan disposisi ini merupakan perubahan sikap, pengetahuan, keterampilan dan nilai atau aspirasi warga belajar Kejar Paket C. Kemampuan adalah wujud penampilan warga belajar dalam lingkungan tertentu, misal dalam lingkungan kehidupan warga belajar Kejar Paket $C$ pada umumnya. Oleh sebab itu hasil kegiatan belajar harus dapat dibandingkan dalam perubahan tingkah laku warga belajar sebelum memasuki kegiatan belajar dan setelah melalukan kegiatan belajar.

Pelaksanaan pembelajaran Paket $\mathrm{C}$ di Desa Tanjungpakis tidak terlepas dari kurikulum yang telah ditetapkan, yang meliputi pendidikan umum dan pendidikan keterampilan. Pelaksanaan pembelajaran Paket $\mathrm{C}$ merupakan proses interaksi edukatif antara warga belajar dengan komponen-komponen pembelajaran lainnya, seperti masukan sarana, masukan lingkungan, dan masukan lain. Sudjana (2004, p.34) yang mengemukakan bahwa proses pembelajaran yang berlang- 


\section{Jurnal Pendidikan dan Pemberdayaan Masyarakat, 3 (2), November 2016 - 131}

Dayat Hidayat

sung melibatkan komponen-komponen sebagai berikut: (1) Masukan sarana (instrumental input) meliputi keseluruhan sumber dan fasilitas yang memungkinan bagi seseorang atau kelompok dapat melakukan kegiatan belajar; (2) Masukan mentah (raw input) yaitu peserta didik (warga belajar) dengan berbagai karakteristiknya yang dimilikinya; (3) Masukan lingkungan (environmental input) yaitu faktor lingkungan yang menunjang atau mendorong berjalannya program pendidikan; (4) Proses yang menyangkut interaksi antara masukan sarana, terutama pendidik dengan masukan mentah, yaitu peserta didik (warga belajar); (5) Keluaran (out put) yaitu kuantitas lulusan yang disertai dengan kualitas perubahan tingkah laku yang didapat melalui kegiatan belajar-membelajarkan; (6) Masukan lain (other input) adalah daya dukung lain yang memungkinkan para peserta didik dan lulusan dapat menggunakan kemampuan yang telah dimiliki untuk kemajuan kehidupannya; (7) Pengaruh (impact) yang menyangkut hasil yang telah dicapai oleh peserta didik dan lulusan.

Sebagai proses pembelajaran, Kejar Paket $\mathrm{C}$ merupakan proses berlangsungnya pembelajaran itu sendiri. Belajar pertamatama dimulai dari diri warga belajar melakukan proses belajar. Belajar merupakan suatu kegiatan yang bertujuan untuk mengembangkan diri melalui proses penyesuaian tingkah laku. Penyesuaian tingkah laku yang terwujud karena belajar, bukan akibat langsung dari pertumbuhan orang yang belajar itu. Ia melakukan kegiatan belajar dengan menyesuaikan tingkah lakunya dalam upaya untuk meningkatkan kualitas kehidupannya. Proses pembelajaran terjadi apabila situasi stimulus bersama dengan isi ingatan mempengaruhi peserta didik sedemikian rupa sehingga perbuatannya (performance) berubah dari waktu sebelum ia mengalami situasi itu ke waktu sesudah ia mengalami situasi tadi.

Pendekatan atau strategi yang digunakan tutor dalam pembelajaran program Kejar Paket $C$ adalah partisipatif sehingga dapat memberikan kesempatan seluas-luasnya kepada warga belajar untuk terlibat dalam perencanaan, pelaksanaan, dan penilaian pembelajaran. Pendekatan ini menekankan bahwa warga belajar adalah pemegang peran dalam proses keseluruhan kegiatan pembelajaran, sedangkan pendidik berfungsi untuk memfasilitasi warga belajar dalam melakukan kegiatan pembelajaran. Metode yang digunakan dalam pembelajaran program Kejar Paket $C$ ini adalah kelompok pada masing-masing kelas. Teknik pembelajaran yang digunakan dalam pembelajaran program Kejar Paket $C$ adalah: (1) ceramah, (2) tanya jawab, (3) demontrasi, (4) penugasan (drill), (5) kerja kelompok, dan (6) praktek lapangan. Media yang digunakan dalam pembelajaran program Kejar Paket $C$ antara lain adalah buku-buku Paket, gambar dan alat peraga. Media tersebut digunakan untuk memperlancar proses pembelajaran.

Berkaitan dengan proses pembelajaran, Sudjana (2004) memberikan formula pembelajaran yang dapat dirumuskan sebagai berikut: $\mathrm{Pb}=f \mathrm{P}(\mathrm{m} \mathrm{S} x$ y $z$ ). "Pembelajaran adalah fungsi (f) untuk membelajarkan $(\mathrm{m})$ peserta didik (S) terhadap materi pembelajaran (x) untuk mencapai hasil belajar (y) yang menimbulkan pengaruh belajar (z)". Berdasarkan rumus formula pembelajaran tersebut dapat diketahui bahwa fungsi pembelajaran adalah untuk membantu, membimbing, melatih, memelihara, merawat, menumbuhkan, mendorong, membentuk, meluruskan, menilai, dan mengembangkan kemampuan peserta didik, baik pengetahuan, keterampilan dan sikap yang menimbulkan pengaruh positif bagi hidup dan penghidupan peserta didik.

Proses pembelajaran Kejar Paket C melibatkan berbagai unsur-unsur pembelajaran. Kegiatan pembelajaran Kejar Paket C sebagai proses memiliki unsur-unsur tersendiri yang membedakan antara kegiatan belajar dan kegiatan bukan belajar. Unsurunsur tersebut mencakup tujuan yang ingin dicapai, motivasi, hambatan, stimulus dari lingkungan, persepsi dan respon. Setiap warga belajar Kejar Paket $C$ dapat menyusun tujuan belajar sesuai dengan kebutuhannya. Warga belajar dapat melakukan kegiatan belajar untuk mencapat tujuan tersebut. Kegiatan belajar untuk mencapai tujuan belajar tidak akan terjadi apabila warga belajar tidak termotivasi untuk belajar. Kesulitan belajar 


\section{Jurnal Pendidikan dan Pemberdayaan Masyarakat, 3 (2), November 2016 - 132}

Dayat Hidayat

merupakan hambatan bagi upaya warga belajar dalam mencapai tujuan belajar Kejar Paket C. Kegiatan belajar sebagai suatu proses pencapaian tujuan belajar, tentunya memiliki tingkatan-tingkatan kesulitan. Warga belajar akan menghadapi kesulitan apabila tujuan belajar yang ditetapkan oleh lembaga penyelenggara pendidikan dan tujuan yang diinginkan oleh masyarakat sering tidak sesuai dengan tujuan yang dinyatakan oleh warga belajar Kejar Paket C. Dengan demikian, upaya menyerasikan ketiga jenis tujuan, yaitu yang diajukan oleh lembaga, masyarakat, dan warga belajar ke dalam tujuan yang bermakna, merupakan upaya yang harus dilakukan oleh para tutor program Kejar Paket C.

Stimulus dari lingkungan belajar dapat timbul dalam situasi belajar selama kegiatan belajar Kejar Paket $C$ berlangsung. Stimulus atau rangsangan yang datang dari lingkungan sering mendorong warga belajar untuk memenuhi kebutuhan belajarnya melalui kegiatan yang berbeda-beda. Sebagai akibatnya, warga belajar sering melakukan kegiatan yang tidak dikehendaki oleh tutor. Lembaga penyelenggara Kejar Paket $\mathrm{C}$ hendaknya mengatasi hal tersebut dengan terlebih dahulu memahami kebutuhan belajar yang dirasakan oleh warga belajar. Motivasi belajar adalah kekuatan penting dalam kegiatan pembelajaran. Pemahaman atau persepsi terhadap situasi belajar akan tergantung pada latar belakang kehidupan, pengalaman belajar, dan kesungguhan warga belajar terhadap kegiatan belajar Kejar Paket $C$ yang sedang berlangsung. Setelah warga belajar membuat keputusan tentang tujuan belajar yang ingin dicapai dan memahami stimulus dari lingkungan dalam situasi belajar.

Pada umumnya warga belajar yang mengikuti program pembelajaran Kejar Paket $C$ menunjukkan minat dan motivasi yang cukup tinggi. Kondisi ini ditandai oleh tingginya tingkat kehadiran warga belajar dalam mengikuti pembelajaran yang dilakukan. Tutor memberikan materi pembelajaran program Paket $C$ dengan menggunakan pendekatan partisipatif yang melibatkan secara aktif warga belajar terutama pada tahap pelaksanaan dan penilaian program.
Pembelajaran Kejar Paket C di Desa Tanjungpakis diselenggarakan untuk menghadapi berbagai permasalahan seperti menangani kebutuhan belajar masyarakat yang tidak dapat dipenuhi melalui jalur pendidikan formal dalam meningkatkan keterampilan fungsional untuk mengembangkan kewirausahaan masyarakat. Pendidikan nonformal satuan Kejar Paket $C$ yang mengintegrasikan kegiatan belajar dan berusaha, baik di bidang industri dan perdagangan maupun jasa, sesuai dengan kebutuhan peserta didik dan sumber-sumber yang tersedia di lingkungannya, pada dasarnya telah menyentuh upaya pembinaan dan pengembangan kewirausahaan (Sudjana, 2004, p.13o). Pendidikan nonformal adalah setiap kegiatan yang terorganisasi, diselenggarakan di luar pendidikan persekolahan, diselenggarakan secara tersendiri atau merupakan bagian penting dari suatu kegiatan dengan maksud memberikan layanan khusus kepada warga belajar dalam mencapai tujuan belajar (Coombs, 1973, p. 11 dalam Kamil, 2009, p.14).

Pembelajaran model partisipatif dalam penyelenggaraan Kejar Paket $C$ merupakan proses pembelajaran bagi warga belajar untuk memperoleh keterampilan fungsional yang berguna untuk meningkatkan terutama taraf kehidupan perekonomiannya. Pembelajaran partisipatif diartikan sebagai upaya sumber belajar untuk mengikutsertakan warga belajar dalam kegiatan pembelajaran. Keikutsertaan warga belajar itu diwujudkan dalam tiga tahapan yaitu perencanaan program (program planning), pelaksanaan program (program implementation) dan penilaian program (program evaluation) kegiatan pembelajaran (Sudjana, 2004, p. 117).

Lebih lanjut Kartika (2011, pp. 11-12) mengemukakan bahwa pembelajaran partisipatif didasarkan pada prinsip-prinsip sebagai berikut: (1) Berdasarkan kebutuhan belajar (learning needs based). Sumber informasi tentang kebutuhan belajar adalah peserta atau calon peserta. Kebutuhan ini dapat diidentifikasi dari lembaga atau organisasi yang memberi tugas kepada peserta dari pihak yang menjadi sasaran pelayanan lembaga atau organisasi dimana peserta bekerja atau mendapat tugas; (2) Berorientasi pada tujuan kegiatan belajar (learning goals and 


\section{Jurnal Pendidikan dan Pemberdayaan Masyarakat, 3 (2), November 2016 - 133}

Dayat Hidayat

objectives oriented). Tujuan pembelajaran disusun oleh sumber belajar bersama peserta, dengan mempertimbangkan pengelaman peserta, potensi yang dimiliki serta sumbersumber yang tersedia di lingkungan kehidupan mereka serta kemungkinan hambatan-hambatan yang muncul dalam kegiatan pembelajaran; (3) Berpusat pada peserta (participant centered). Peserta diikutsertakan dan harus berperan penting dalam perencanaan, pelaksanaan dan evaluasi; (4) Belajar berdasarkan pengalaman (experiential learning). Proses pembelajaran partisipatif disusun dan dilaksanakan dengan berangkat dari hal-hal yang telah dipelajari berupa pengetahuan, nilai, dan keterampilan yang dimiliki peserta serta dari pengalaman peserta, baik dari pengalaman dalam tugas pekerjaan sehari-hari meupun pengalaman nyata yang diangkat dari tugas atau pekerjaan peserta didik.

Pembelajaran partisipatif merupakan cara yang ditempuh untuk meningkatkan kerja sama dan peran serta dalam pengambilan keputusan. Pendekatan ini banyak diterapkan dalam pelatihan pengembangan tim dan perencanaan pembangunan. Partisipasi menjadi dasar pengembangan interaksi pembelajar dengan lingkungan untuk memperkuat tugas dan fungsi organisasi. (Sumpeno, 2009, p.124).

Ada tahap akhir proses pembelajaran dilaksanakan penilaian proses dan hasil. Penilaian di sini dimaksudkan dengan jenis penilaian yang digunakan, tes yang benarbenar potensial dapat mengukur ketercapaian tujuan pembelajaran program Kejar Paket $C$, dan bagaimana menetapkan ukuran keberhasilan itu sendiri. Penilaian dilakukan terhadap proses dan hasil yang dicapai peserta itu sendiri, untuk itu alat yang akan digunakan perlu disiapkan oleh instruktur yang akan mengelola kegiatan pembelajaran. Penilaian pembelajaran program Kejar Paket $\mathrm{C}$ dilaksanakan oleh masing-masing tutor di akhir pemberian materi pembelajaran. Penilaian tersebut dipadukan dan dipantau oleh penyelenggara melalui lembar observasi. Evaluasi secara menyeluruh setelah warga belajar mengikuti pembelajaran Kejar Paket $C$ dilakukan pihak penyelenggara yang bekerja sama dengan Dinas Pendidikan kabupaten dan Dinas Tenaga Kerja Kabupaten Karawang. Informasi yang berkaitan dengan hasil pembelajaran Kejar Paket C diperoleh melalui observasi, wawancara dan studi dokumentasi terhadap satu orang tutor dan empat orang warga belajar.

Penilaian program Kejar Paket $C$ yang difokuskan pada proses pembelajaran selama kegiatan berlangsung, meliputi kemampuan tutor dalam menyampaikan materi, kemampuan warga belajar menerima mateeri pembalajaran. Dengan demikian aspek yang dievaluasi dalam pembelajaran program Kejar Paket C ini meliputi: (1) penilaian kognitif, (2) afektif dan (3) psikomotor. Keberhasilan program Kejar Paket $C$ ini tentu saja tanggung jawab dari pimpinan Desa Tanjungpakis selaku penyelenggara. Hal ini akan diperlihatkan oleh Kepala Desa Tanjungpakis dengan cara berusaha untuk meningkatkan kinerja para pengelola PKBM. Selain itu Kepala Desa Tanjungpakis selaku penyelenggara program Kejar Paket $C$ selalu berkoordinasi dengan Dinas Pendidikan dan Kebudayaan kabupaten serta selalu melaporkan perkembangan program Kejar Paket $C$ ini minimal satu bulan sekali. Pengawasan dan pengendalian terhadap kelangsungan serta keberhasilan program Kejar Paket C dilakukan oleh berbagai pihak antara lain oleh Dinas Pendidikan dan Kebudayaan Kasi Pendidikan Masyarakat Kabupaten Karawang, yang secara rutin dan berkala akan mengadakan monitoring dan pemantauan.

Tahap penilaian pembelajaran merupakan penting untuk mengetahui keberhasilan program Kejar Paket C. Penialaian dilakukan untuk menghimpun, mengolah dan menyajikan data atu informasi yang dapat digunakan sebagai masukan dalam pengambilan keputusan (Sudjana, 2004, p.130). Penilaian pembelajaran dilakukan bersama antara warga belajar dan pengelola Kejar Paket C. Melalui kegiatan penilaian pembelajaran keterampilan fungsional berwirausaha Kejar Paket C, warga belajar mengetahui sejauhmana peningkatan pendapatan yang telah dialami dan dicapai oleh mereka melalui kegiatan belajar. 


\section{Jurnal Pendidikan dan Pemberdayaan Masyarakat, 3 (2), November 2016 - 134}

Dayat Hidayat

\section{Dampak Pembelajaran Partisipatif bagi Pemberdayaan Ekonomi Warga Belajar}

Penerapan model pembelajaran partisipatif model keterampilan fungsional bagi warga belajar Kejar Paket C diharapkan memberikan dampak bagi pengembangan usaha yang dilakukan dalam mengembangkan keterampilannya. Contohnya, sesuai dengan potensi lokal warga belajar Paket $C$ yang mengembangkan keterampilan fungsional budi daya jamur merang, misalnya. Warga belajar memperoleh kesempatan untuk mengikuti kejar Paket $C$ untuk bidang usahanya sehingga dapat meningkatkan pengetahuan dan keterampilan membudidayakan jamur merang dalam mengembangkan kewirausahaannya. Tujuan dia mengikuti adalah agar memiliki pengetahuan dan keterampilan cara pemilihan lokasi penanam bibit, cara penentuan waktu penanaman bibit, cara penyiapan kubung, penanaman bibit, cara penyiapan bibit, cara penanaman bibit, cara pemupukan penanaman bibit, cara pengairan/penyiraman penanaman bibit, cara pengendalian organisme pengganggu tanaman, cara sanitasi/pemeliharaan kubung, cara pemanenan, cara pembersihan, serta grading/pemasaran jamur merang.

Menurut warga belajar materi yang diberikan tersebut sudah sesuai dengan minat dan kebutuhan belajarnya. Program pembelajaran keterampilan budi daya jamur merang dilaksanakan selama satu hari dalam satu minggu. Dia mengikuti program tersebut selama dua bulan. $\mathrm{R}_{4}$ mengikuti pembelajaran keterampilan budi daya jamur merang selama 2 jam dalam sehari. Menurut warga belajar materi yang terdiri atas 30\% teori dan $70 \%$ praktek yang diberikan sangat tepat. Setiap petani jamur merang terlebih dahulu memperoleh teori tentang kemudian dilanjutkan dengan praktek.

"Dampak adalah merupakan tingkat pencapaian tujuan dan sasaran pembelajaran". Tujuan umum pembelajaran pada dasarnya menjadi arahan utama bagi penyelenggara program dan merupakan tolok ukur keberhasilan program pembelajaran itu (Sudjana, 2004, p.38). Dampak merupakan pengaruh kuat yang mendatangkan akibat, baik negatif positif terhadap kehidupan seseorang. Dampak positif yang diharapkan warga belajar Kejar Paket $C$ setelah memperoleh pengetahuan, sikap dan keterampilan budi daya jamur adalah terbukanya kesempatan untuk meningkatkan kemandirian ekonomi kehidupannya.

Salah seorang warga belajar Paket $\mathrm{C}$ di Desa Tanjungpakis, mengemukakan bahwa dia merasa bangga dan senang karena setelah mengikuti program Kejar Paket $C$ bidang keterampilan budi daya jamur merang karena dapat memperoleh pendapatan walaupun belum terlalu besar. Dalam mengembangkan usahanya, warga belajar ini memperoleh pendapatan rata-rata Rp. 550.000 dalam satu bulan. Setelah mengikuti pembelajaran keterampilan budi daya jamur merang, dia memperoleh pendapatan ratarata Rp. 1.00o.ooo. Dengan demikian warga belajar Kejar Paket $C$ mengalami peningkatan pendapatan sebesar Rp. 450.00o dalam satu bulan setelah mengikuti Kejar Paket $C$ di bidang keterampilan budi daya jamur merang.

Berkaitan dengan dampak pembelajaran keterampilan fungsional berwirausaha bagi pemberdayaan warga belajar Kejar Paket $C$ ini sejalan dengan pendapat Suryono \& Sumarno (2013, p.7) yang mengemukakan bahwa tujuan yang ingin dicapai oleh program pembelajaran partisipatif keterampilan fungsional berwirausaha adalah untuk (1) membentuk atau mengembangkan unit usaha/inkubator bisinis dan penguatan kelembagaan sebagai rintisan sentra kewirausahaan masyarakat sesuai dengan potensi yang dimiliki, (2) menciptakan peluang sumber pendanaan lembaga yang berasal dari keuntungan unit usaha/inkubatur bisnis yang dikembangkan, dan (3) meningkatkan keberaksaraan wirausaha peserta didik melalui peningkatan pengetahuan, sikap, keterampilan, dan keberanian berusaha mandiri secara perorangan atau bagian dari inkubator bisnis yang dikembangkan oleh lembaga.

Pembelajaran kewirausahaan dilaksanakan dengan menggunakan kurikulum yang mengacu pada standar kompetensi kewirausahaan yang telah ditetapkan untuk: (1) mengidentifikasi jenis-jenis usaha yang berpeluang untuk dikembangkan sesuai 


\section{Jurnal Pendidikan dan Pemberdayaan Masyarakat, 3 (2), November 2016 - 135}

Dayat Hidayat

dengan kondisi lingkungan dan pasar, (2) menuliskan dan mengkomunikasikan rancangan usaha yang dikembangkan, (3) menguasai keterampilan produksi tertentu sesuai usaha yang dikembangkan, (4) memasarkan produk usaha, (5) melakukan analisis perhitungan rugi/laba, (6) menjalin kemitraan, dan (7) memelihara dan mengembangkan kompetensi keberaksaraan dalam menjalankan usaha (Suryono, \& Sumarno (2013, p.8).

Program Paket $\mathrm{C}$ yang diikuti warga belajar memberikan dampak yang baik dalam kehidupan ekonomi keluarganya. Dampak positif yang diharapkan warga belajar Kejar Paket $C$ ini, ia kemukakan bahwa setelah memperoleh pengetahuan, sikap dan keterampilan budi daya jamur merang adalah terbukanya kesempatan untuk meningkatkan pendapatan ekonomi kehidupannya. Menurut dia, ini merupakan langkah awal untuk meningkatkan kemandirian ekonomi keluarganya sebagai dampak mengikuti program Kejar paket C di Desa Tanjungpakis.

Dampak pembelajaran keterampilan fungsional berwirausaha yang telah diperoleh warga belajar Kejar Paket C tampak berdasarkan pada perubahan pengetahuan, sikap dan keterampilannya, dalam mengenal bahan dan alat yang digunakan dengan indikator mengenal jenis-jenis bahan dan jenisjenis alat yang digunakan dalam berusaha. Pengalaman belajar yang diperoleh warga belajar Paket $\mathrm{C}$ ini adalah kemampuan memilih bahan baku dan menggunakan alat yang diperlukan untuk mengolah hasil usaha. Pengetahuan dan keterampilan tentang cara mengolah bahan mentah menjadi bahan jadi dengan indikator praktek keterampilan berwirausaha. Adapun pengalaman belajar praktek membuat hasil usaha yang diharapkan adalah mampu membuat hasil produksi untuk mudah dipasarkan dengan indikator mampu menghitung laba rugi hasil pemasaran produksi.

Dampak pembelajaran keterampilan fungsional berwirausaha ini merupakan proses pemberdayaan masyarakat pada aspek peningkatan ekonomi keluarga. Pemberdayaan masyarakat dan pertisipasi merupakan strategi dalam paradigma pembangunan yang bertumpu pada rakyat (people centered development). Strategi ini menyadari pentingnya kapasitas masyarakat untuk meningkatkan kemandirian dean kekuatan internal, melalui kesanggupan untuk melakukan kontrol internal atas sumber daya material dan non-material yang penting melalui redistribusi modal atau kepemilikan (Korten, 1992) dalam Adimiharja \& Hikmat, (2004, p.1).

\section{SIMPULAN DAN SARAN}

\section{Kondisi Empiris Program Kejar Paket C}

Program Kejar Paket C, di Desa Tanjungpakis, dalam pelaskanaannya, cukup mengalami keberhasilan. Program Kejar Paket $C$ yang didirikan sudah dapat berlangsung dengan baik dan lancar. 20 orang warga belajar yang mengikuti program Kejar Paket $C$ di Desa Tanjungpakis. Bahan pembelajaran disesuaikan dengan mata pelajaran setara SLTA. Sedangkan untuk pembelajaran keterampilan menekankan pada kewirausahaan yang berbasis pada potensi lokal.

\section{Proses Pembelajaran Partisipatif Model Keterampilan Fungsional dan Kewirausahaan}

Program Kejar Paket C melibatkan warga belajar dalam merencanakan, melaksanakan dan menilai hasil pembelajaran keterampilan fungsional berwirausaha. Tujuan pembelajaran disusun untuk meningkatkan pengetahuan, keterampilan dan sikap kewirausahaan warga belajar Kejar Paket C yang berdampak pada peningkatan kesempatan kerja dan pemberdayaan atau kemandirian ekonomi warga belajar. Pembelajaran keterampilan fungsional berwirausaha berkaitan dengan pengetahuan, sikap dan keterampilan berwirausaha tentang cara mengolah bahan mentah menjadi bahan jadi, dan cara memasarkan hasil produksi. Metode yang digunakan antara lain ceramah, tanya jawab, demontrasi, penugasan (drill), kerja kelompok, dan praktek lapangan. Sarana dan media yang digunakan meliputi adalah buku-buku dan alat peraga. Untuk mengukur keberhasilan proses pembelajaran, tutor melaksanakan penilaian, 


\section{Jurnal Pendidikan dan Pemberdayaan Masyarakat, 3 (2), November 2016 - 136}

Dayat Hidayat

baik teori dan kemampuan keterampilan berwirausaha warga belajar.

\section{Dampak Pembelajaran Partisipatif Bagi Pemberdayaan Ekonomi Warga Belajar}

Dampak pembelajaran yang telah diper-oleh warga belajar Kejar Paket C selama mengikuti program pembelajaran keterampilan berdasarkan ranah kognitif, afektif, dan keterampilannya, dalam mengenal bahan dan alat yang digunakan dengan indikator mengenal jenis-jenis bahan dan jenis-jenis alat yang digunakan. Pengetahuan dan keterampilan tentang cara mengolah bahan mentah menjadi bahan jadi dengan indikator praktek keterampilan yang berkaitan dengan cara memasarkan hasil produksi dengan indikator mampu menghitung laba rugi hasil pemasaran hasil produksi. Dampak pembelajaran keterampilan fungsional berwirausaha dapat membuka kesempatan bagi warga belajar untuk meningkatkan kemandirian ekonomi sehingga meningkat pendapatan keluarganya.

Berdasarkan hasil penelitian yang telah diperoleh, maka penulis memberikan saransaran sebagai berikut ini: (1) Kepala Desa Tanjungpakis memberikan pendampingan untuk memberikan akses bantuan permodalan ke Bank bagi warga belajar Kejar Paket $C$ dengan bunga pengembalian yang rendah untuk meningkatkan hasil produksinya; (2) Kepala Desa Tanjungpakis memberikan pendampingan dalam mengembangkan jaringan kemitraan usaha sehingga dapat menyalurkan hasil produksi warga belajar Kejar Paket $\mathrm{C}$ ke pasaran sehingga dapat lebih meningkatkan pendapatan ekonomi keluarga warga belajar; (3) Kepada Dinas Pendidikan dan Kebudayaan Kabupaten Karawang melalui Bidang Pendidikan Nonformal dan Informal (PNFI) melakukan pendampingan melalui keberlanjutan pemberian kegiatan pelatihan kewirausahaan untuk meningkatkan keterampilan warga belajar Kejar Paket $C$ sehingga hasil produksi dan pemasarannya semakin berkembang.

\section{DAFTAR PUSTAKA}

Abdulhak, I. (1995). Metodologi pembelajaran pada pendidikan orang dewasa. Bandung: Cipta Intelektual.
Adimiharja, K. \& Hikmat, H. (2004). Participatory research appraisal dalam pelaksanaan pengabdian kepada masyarakat. Bandung: Humaniora Utama Press (HUP).

Alma, B. (2007). Kewirausahaan. Bandung: Alfabeta.

Emzir. (2010). Metodelogi penelitian kualitatif. Analisis Data. Jakarta: Raja Grasindo.

Borg and Gall. (1979). Education research an introduction. New York: Allyn and Bacon Inc.

Cresswell, J.W. (2013). Research design. Yogyakarta: Pustaka Pelajar.

Kartika, I.A. (2011). Mengelola pelatihan partisipatif. Bandung: Alfabeta.

Kamil, M. (2009). Pendidikan nonformal. Bandung: Alfabeta.

Lincolin, A. S., Elan. dkk. (2011). Strategi pembangunan perdesaan berbasis lokal. Yogyakarta: UPP STIM YKPN.

Milles, M.B. \& Huberman, A.M. (1994). Analisis data kualitatif. Jakarta: Universitas Indonesia Press.

Moleong, L.J. (2010). Metodologi penelitian kualitatif. Bandung: PT. Remaja Rosdakarya.

Milan J.M. \& Schumacher, S. (1997). Research in education. New York: Addison Wesley Longman. Inc.

Nasution, S. (1992). Metode penelitian naturalistik kualitatif. Bandung: Tarsito.

Sudjana, D. (2004). Pendidikan nonformal, wawasan, sejarah perkembangan, falsafah, teori pendukung, azas. Bandung: Falah Production.

Sudjana, D. (2004). Strategi kegiatan belajar mengajar dalam pendidikan nonformal. Bandung: Falah Production.

Sudjana, D. (2004). Metode dan teknik pembelajaran partisipasif dalam pendidikan non formal. Bandung: Falah Production.

Sudjana, D. (2007). Manajemen program pendidikan, untuk pendidikan nonformal, dan pengembangan sumber 
Jurnal Pendidikan dan Pemberdayaan Masyarakat, 3 (2), November 2016 - 137 Dayat Hidayat

daya manusia. Bandung: Falah Suryana. (2007). Kewirausahaan, pedoman Production. praktis kiat dan proses menuju sukses.

Suherman, E. (2010). Desain pembelajaran kewirausahaan. Bandung: Alfabeta.

Sumpeno, W. (2009). Sekolah masyarakat. Yogyakarta: Pustaka Pelajar Jakarta: Salemba Empat.

Suryono Y, \& Sumarno. (2013). Pembelajaran kewirausahaan masyarakat. Yogyakarta: Aditya Media. 